\title{
Dynamic Relationship between Stock Exchange and Exchange Rate: a Case of Emerging Economies in Context of GFC
}

\author{
Ghulam Mujtaba Kayani, Xiaofeng Hui *, Saqib Gulzar \\ ${ }^{3}$ Department of Management Sciences, Harbin Institute of Technology, Harbin, 150001, China \\ COMSATS Institute of Information Technology, Wah, Pakistan
}

\begin{abstract}
In this study we analyze the dynamic short-run and long-run relationship between the Stock returns and Exchange rate; the study identifies the impact of exogenous shocks and we have employed various econometric techniques to like multivariate granger causality test, Cointegration analysis and Vector autoregession model. Daily data has been taken for the analysis starting from January 1, 2007 to September 30, 2011 which has been divided into three parts (before, during and after) financial crisis period. The results show a long-term Cointegration among the variables in all cases whereas, in short-term during the crisis period it shows that Global stock returns have a significant impact on China and Pakistan but not on their Exchange rates and also it has significant impact on India and Brazilian Exchange rate but not on their stock returns.
\end{abstract}

Keywords-emerging market economies; exchange rate; multivariate granger causality; cointegration analysis and VAR model

\section{INTRODUCTION}

In the era of globalization the world has become a global village. The buying and selling of products in international markets have brought financial sector closer to each other. It is heavily acknowledged that over the years financial markets have relatively integrated. The vibrant relationship between stock prices and foreign exchange rates has been discussed by various economists as they have a key role in the development of country's economy. In 2008, the global financial crisis had a great effect on the economic activities of the developed and emerging markets (Brahima, 2013) explains in his study. The two main channels that have been discussed in the literature to study the spread of this financial crisis are through trade channel and financing channel. First considering the concept of trade channel, the increase or a decrease in trade of an economy affects the exchange rate. On the other hand, the financing activity is through the capital market. Due to many financial events the exchange rate and stock prices have tend to move in the same wave. So, it became an integral topic for the economists to investigate their dynamics.

Classical economic theory proposes a relation between the behavior of stock market performance and exchange rate. In their study (Dornbusch and Fisher, 1980) explains that movement exchange rate affects the international competiveness and trade balance, as a result the real output of the country and which affects the cash flows of companies and their stock prices. Stock market movement may also affect the exchange rate explained in monetarist models of exchange rate determination (Gavin, 1989). Portfolio-balance model discusses the similar study (Frankel, 1987). In 1900s the financial liberalization of capital inflow and stock markets was followed by a boom in the number of cross border transactions of currencies and securities. This relationship between financial stock prices and exchange rate has emerged because of heavy amount of capital flow in international financial markets (Tian and Ma, 2010). Chinese Yuan has been pegged with US dollar for over 10 years at the rate of 8.3 to one US dollar. The study of (S. Deng and C. Yang, 2008) has shown a long-term cointegration among these markets of China but their study does not support the stock price led exchange rate relationship. The study done using the Indian market (Rahman and Uddin, 2009), (Bhattacharya and Mukherjee, 2003) and (Muhammad and Rasheed, 2002) suggests that there is no relation at all between exchange rates and stock prices and also supports of no causal relationship between the stock prices and exchange rate.

The global financial crisis has created an impact on the stock prices of emerging markets (Kenourgios, 2012) and (Kayani et al., 2013). Previous literature is mainly focused on relationship between the domestic stock market and exchange rate (see e.g. Caporale and Pittis, 1997). The studies that address the impact of global stock return on this vibrant area are not focused on emerging market economies (see e.g. Kate and Fabiola, 2005) and (Nieh and Lee, 2002). The studies make a room to investigate its impact of global stock return on stock returns of emerging market economies and exchange rates (during short-run and long-run) in perspective of global financial crisis. In this study we will address this issue.

Hypothesis of our study are:

H1: There is an impact of US stock returns on the causality between emerging economies stock returns and their exchange rate.

H2: US stock return affects on the stock returns of emerging economies stock returns and their exchange rate in short-run.

$\mathrm{H} 2 \mathrm{~b}$ : US stock return affects on the stock returns of emerging economies stock returns and their exchange rate in long-run. 


\section{METHODOLOGY}

The discussed model is given as follow:

\section{A. Data and Preliminary Analysis}

For the analysis of our study we examined the daily observations of stock returns of Brazil, India, China, Pakistan, Russia and USA and exchange rates (with USD). Data of real exchange rate has been taken as it explains the batter position of an economy compared to others. The sample is from January 2, 2007 to December 31, 2011. In his study (Dungey et al. 2005) states the tests of financial contagion are sensitive to the definition of crisis period. We have divided our data into three different periods with respect to financial crisis period to make analysis more accurate.

\section{B. Econometric Methodology}

The econometric methodology we employed for the analysis starts with ADF Unit root test. Stationarity of time series data is an integral part of analysis for the purpose Augmented Dickey-Fuller (ADF) test has been employed. The ADF test shows significant results which are not presented due to brevity.

As the data series is stationary that reflects to the finite mean and finite auto-covariance of the series at the level. We shall apply the subsequent analysis on the stationary series. The data of each country's stock return and exchange rate shall be regressed with the Global stock exchange in order to know the effect on each country. Caporale and Pittis (1997) in their study discussed the first order bivariate VAR and they applied a condition that both eigenvalues are equal to 1 , that means no Cointegration or causality among the variables. It further adds that how the omission of third variable from a bivariate VAR can affect, which causes a) none b) one, c) both. The dilemma has been discussed by (Kate and Fabiola, 2005) in their study which emphasis on the importance of inclusion of third variables (while studying the dynamics of stock exchange and exchange for Pacific Basin Stock markets). So, this study discusses the third element and that is global stock returns.

The relationship between the global stock market, domestic stock market and exchange rate can be represented as

$$
R_{t}^{E M E}=\alpha_{0}+\alpha_{1} X_{t}^{E M E}+\alpha_{2} R_{t}^{U S}+\varepsilon_{t}
$$

Where the domestic stock return of Emerging Economy is $R_{t}^{E M E}$ while $R_{t}^{U S}$ is the global stock return and $X_{t}^{E M E}$ is the exchange rate of Emerging Market Economy. Existence of co-integration becomes the cause of causality among variables explained by C.W.J Granger (1988). So, we test the long-term Cointegration among the stock returns and exchange rates. If co-integration does not exist, we apply VAR model which is as follow

$$
\begin{aligned}
& \Delta y_{t}=c_{1}+\sum_{i=1}^{k} \alpha_{1 i} \Delta y_{t-i}+\sum_{i=1}^{k} \beta_{1 i} \Delta x_{t-i}+\varepsilon_{1 t} \\
& \Delta x_{t}=c_{2}+\sum_{i=1}^{k} \alpha_{2 i} \Delta y_{t-i}+\sum_{i=1}^{k} \beta_{2 i} \Delta x_{t-i}+\varepsilon_{2 t}
\end{aligned}
$$

Whereas, in the above equations ' $\mathbf{y}_{\mathrm{t}}$ ' and ' $\mathbf{x}_{\mathrm{t}}$ ' represents stock returns and exchange rates of the economies and $\varepsilon_{\mathrm{t}}$ is the error term.

$\mathrm{H}_{\mathrm{o}}$ : Exchange rate do not cause Stock returns (if $\beta_{11} \ldots \ldots \ldots \beta_{1 \mathrm{k}}=0$; reject $\mathrm{H}_{\mathrm{o}}$ )

Same as,

$\mathrm{H}_{\mathrm{o}}$ : Stock returns do not cause Exchange rate (if $\alpha_{11} \ldots \ldots \ldots \alpha_{1 \mathrm{k}}=0$; reject $\mathrm{H}_{\mathrm{o}}$ )

The causality among the Stock returns and Exchange rates could be determined through VAR (Vector Autoregression) method. In contrast, it could be modelled through VECM (Vector Error Correction Method) if Cointegration exists between ' $\mathbf{y}_{\mathrm{t}}$ ' and ' $\mathbf{x}_{\mathrm{t}}$ '.

$$
\begin{gathered}
\begin{array}{c}
\Delta y_{t}=c_{1}+\sum_{i=1}^{k} \alpha_{1 i} \Delta y_{t-i}+\sum_{i=1}^{k} \beta_{1 i} \Delta x_{t-i}+\delta_{1} E C T_{t-1} \\
+\varepsilon_{1 t}
\end{array} \\
\begin{array}{c}
\Delta x_{t}=c_{2}+\sum_{i=1}^{k} \alpha_{2 i} \Delta y_{t-i}+\sum_{i=1}^{k} \beta_{2 i} \Delta x_{t-i}+\delta_{2} E C T_{t-1} \\
+\varepsilon_{2 t}
\end{array}
\end{gathered}
$$

In the above equation $\mathrm{ECT}_{\mathrm{t}-1}$ is a lagged error correction term whereas $\boldsymbol{\delta}_{1}$ and $\boldsymbol{\delta}_{2}$ are the denotations for the speed of adjustment. The addition of absolute values of $\boldsymbol{\delta}_{1}$ and $\boldsymbol{\delta}_{2}>$ 0 shows the presence of Co-integration which involves the causality among the variables.

$\mathrm{H}_{\mathrm{o}}$ : Exchange rate do not cause Stock returns (if $\beta_{11} \ldots \ldots \ldots . \beta_{1 \mathrm{k}}=0$; reject $\mathrm{H}_{\mathrm{o}}$ )

Same as,

$\mathrm{H}_{\mathrm{o}}$ : Stock returns do not cause Exchange rate (if $\alpha_{11} \ldots \ldots . . \alpha_{1 \mathrm{k}}=0$; reject $\mathrm{H}_{\mathrm{o}}$ )

\section{RESULTS AND FINDINGS}

This study first examines the multivariate granger causality test. The results to this study consent with the claim of the importance of third variable in a bivariate VAR as described by (Kate and Fabiola, 2005) in his study. The results do not show a casual relation between Pakistan's stock return and US stock return in short-run but the Cointegration vector for the trivariate system is statistically significant. In all three phases, Johansen and Juselius Cointegration test to check the long term Cointegration among the global stock returns, domestic stock returns and exchange rate of domestic economy. The results based on both the Trace test and the Maximum Eigen value test, support long-run relationships between the variables, which is an indication of cointegration among the variables. The result of Brazil shows there are 
at most two cointegrating vectors. The result of China, India and Pakistan indicates one cointegrating equation. The result of K. Ni and Q. Ni (2008), S. Deng and C. Yang (2008), Qi Fei and Tian Boping (2009) also shows the long-term Cointegration in case of China. During Crisis period the results of Trace test and Maximum Eigen value test shows at most one cointegrating vector for each economy considered and in after crisis period we find at most one cointegrating equation as a result of Johansen and Juselius Cointegration test.

Results in the table show, ECMt-1 is significant indicating log-run equilibrium relationship among all economies. During Crisis period the results of ECMt-1 for Emerging Market Economies is found significant showing equilibrium in long-run relationship for all economies. In case of Brazil if there is an error in the equilibrium in the short run then $74.3 \%$ of the error is corrected by the global stock returns (NYSE), 92.21\% of the error is corrected by domestic stock returns and $19.34 \%$ by Brazilian Lira. Results also show that there is inertia in domestic stock returns. Moreover, it is found that, in the short run, global stock returns do affect domestic stock returns of Brazil and Brazilian Lira before crisis and during financial crisis but in case of domestic stock returns of Brazil that global stock returns do not affect that but do affect the Brazilian Exchange rate. The results of Chinese Economy represents that $22.49 \%$ of the error is rectified by the ECMt-1 comparing to $11.41 \%$ before the crisis. Whereas in short-run the global stock exchange does affect the domestic stock returns of Shanghai stock exchange before crisis period, during crisis period and after crisis period. The global stock returns does not affect the Yuan-USD exchange rate in short-term during the crisis period. The domestic stock returns of India are capable to correct $6.68 \%$ of the error in the short-run comparing to $89.94 \%$ before crisis period and global stock returns does affect domestic stock returns of India before and after the crisis period but they do not affect during the crisis period. On the other hand, NYSE returns have a significant impact on USD-Exchange rate of India. The result of Pakistan shows a long-run equilibrium and $4.42 \%$ of the error is corrected by the KSE returns comparing to $17.40 \%$ before the crisis period. However, in short-run there is an impact of NYSE returns on the domestic returns of Pakistan before crisis period, during crisis period and after crisis period.

\section{CONCLUSIONS}

In this study we analysed the short-run and long-run dynamics of the domestic stock return, global stock return and exchange rate for the Emerging Market Economies. Our main focus was to check this relationship in perspective of global financial crisis. To understand it more clearly we have divided the analysis into three parts i.e. before financial crisis period, during and after. The First Point of our analysis signifies the importance of US stock returns as an important causing variable and supports the evidence presented in earlier studies (see e.g. Kate and Fabiola, 2005). In addition, it has been found that exists a long-run Cointegration relationship between the domestic stock returns, global stock returns and exchange rate for Emerging Market Economies. Similar, results were found by (Fei and Boping, 2009) in their study to analyse the linkages between the Chinese Exchange rate and domestic Stock returns. Before the crisis period, the results show that Global stock returns do affect the Stock returns of all Emerging Market Economies that build's the initiative to analyse during the crisis period. Moreover, during the crisis period, in shortrun the global stock returns do affect the stock returns of China and Pakistan but not in the case of Brazil and India. At, this point it is important to note the affect on Exchange return which shows the other way i.e. a shortrun affect on Brazil and India but no affect on China and Pakistan. Here, we can make an argument that exchange rate adjustments in the short-run may have prevented a change in the stock returns of Emerging Market Economies in the short-run.

\section{V.ACKNOWLEDGEMENTS}

The research work was supported by National Natural Science Foundation of China under Grant No. 71173060, $70773028,71031003$.

\section{REFERENCES}

[1] Bhattacharya, B. \& Mukherjee, J. "Causal Relationship between Stock Market and Exchange Rate, Foreign Exchange Reserves and Value of Trade Balance: A Case Study for India", Paper presented at the Fifth Annual Conference on Money and Finance in the Indian Economy, January 2003.

[2] Branson, William H. "A model of exchange-rate determination with policy reaction: evidence from monthly data." (1983).

[3] Caporale, G. M., \& Pittis. N., "Causality and forecasting in incomplete systems", Journal of Forecasting, 16(6), 425-437, 1997H. Simpson, Dumb Robots, 3rd ed., Springfield: UOS Press, 2004, pp.6-9.

[4] Coulibaly, Brahima, Horacio Sapriza, and Andrei Zlate. "Financial frictions, trade credit, and the 2008-09 global financial crisis." International Review of Economics \& Finance 26 (2013): 25-38.

[5] Dornbusch, R., Branson, W. H., Kenen, P., Houthakker, H., Hall, R. E., Lawrence, R., ... \& von Furstenburg, G. "Exchange rate economics: where do we stand?". Brookings Papers on Economic Activity, 143-205, (1980)

[6] Dungey*, M., Fry, R., González-Hermosillo, B., \& Martin, V. L. "Empirical modeling of contagion: a review of methodologies". Quantitative Finance, 5(1), 9-24, 2005.

[7] Engle, R.F., Granger, C.W.J., "Cointegration and error correction: representation, estimation and testing". Econometrica 55, 251-277, 1987

[8] Fei Qi, Tian Boping. "LINKAGES BETWEEN EXCHANGE RATES AND STOCK PRICES: EVIDENCE FROM CHINESE FINANCIAL MARKETS" In Proceedings of the IASTED International Conference, vol. 662, p. 077.

[9] Frankel, Jeffrey A., and Kenneth A. Froot. "Using survey data to test some standard propositions regarding exchange rate expectations." (1987)

[10] Gavin, Michael. "The stock market and exchange rate dynamics." Journal of International Money and finance 8, no. 2 (1989): 181-200 
[11] Kayani, Ghulam Mujtaba, Hui Xiaofeng, and Saqib Gulzar. "Financial Contagion: Mean Spillover Effect of US Financial Market to the Emerging Financial Markets in Perspective of Global Financial Crises." Journal of Convergence Information Technology Vol. 8, No.17, December 2013

[12] Kenourgios, D., \& Padhi, P. "Emerging markets and financial crises: Regional, global or isolated shocks?" Journal of Multinational Financial Management, 22(1), 24-38, 2012

[13] Muhammad, N., Rasheed, A., \& Husain, F., "Stock Prices and Exchange Rates: Are they Related? Evidence from South Asian Countries [with Comments]". The Pakistan Development Review, 535-550, 2002.

[14] Nieh, Chien-Chung, and Cheng-Few Lee. "Dynamic relationship between stock prices and exchange rates for G-7 countries." The
Quarterly Review of Economics and Finance 41, no. 4 (2002): 477490.

[15] Phylaktis, K. Kate and Ravazzolo, Fabiola, "Stock prices and exchange rate dynamics". Journal of International Money and Finance, 24(7), 1031-1053, 2005.

[16] Rahman, Md Lutfur, and Jashim Uddin. "Dynamic relationship between stock prices and exchange rates: evidence from three South Asian countries."International Business Research 2.2 (2009): P167.

[17] S. Deng and C. Yang, "An empirical study on the relationship between stock price and exchange rate in China" Journal of Financial Research, 1, 2008, 29-41.

[18] Tian, Gary Gang, and Shiguang Ma. "The relationship between stock returns and the foreign exchange rate: the ARDL approach." Journal of the Asia Pacific economy 15, no. 4 (2010): 490-508.

\section{Appendix}

TABLE IV-A. VECM RESULTS FOR BRAZIL

\begin{tabular}{|c|c|c|c|c|c|c|c|c|c|}
\hline & \multicolumn{3}{|c|}{ Before } & \multicolumn{3}{|c|}{ During } & \multicolumn{3}{|c|}{ After } \\
\hline & NYSE & BM\&F & BRL & NYSE & BM\&F & BRL & NYSE & BM\&F & BRL \\
\hline Coint. Eq. & $\begin{array}{c}-0.7430 \\
(-11.9225)\end{array}$ & $\begin{array}{c}0.9221 \\
(8.0859)\end{array}$ & $\begin{array}{c}-0.1934 \\
(-4.1588)\end{array}$ & $\begin{array}{c}-0.6481 \\
(-3.3722)\end{array}$ & $\begin{array}{c}0.0228 \\
(0.1026)\end{array}$ & $\begin{array}{c}-0.8624 \\
(-7.7403)\end{array}$ & $\begin{array}{c}-0.7351 \\
(-10.5587)\end{array}$ & $\begin{array}{c}-0.0566 \\
(-0.7015)\end{array}$ & $\begin{array}{c}-0.5066 \\
(-12.9529)\end{array}$ \\
\hline NYSE(-1) & $\begin{array}{c}-0.2116 \\
(-4.5603)\end{array}$ & $\begin{array}{c}-0.4039 \\
(-4.7562)\end{array}$ & $\begin{array}{c}0.1094 \\
(3.1608)\end{array}$ & $\begin{array}{c}-0.2360 \\
(-1.5045)\end{array}$ & $\begin{array}{c}-0.0508 \\
(-0.2797)\end{array}$ & $\begin{array}{c}0.4869 \\
(5.3550)\end{array}$ & $\begin{array}{l}-0.2092 \\
-3.3904\end{array}$ & $\begin{array}{c}0.1335 \\
(1.8680)\end{array}$ & $\begin{array}{c}0.2924 \\
(8.4357)\end{array}$ \\
\hline NYSE(-2) & & & & $\begin{array}{c}-0.2457 \\
(-2.3038)\end{array}$ & $\begin{array}{c}-0.0092 \\
(-0.0745)\end{array}$ & $\begin{array}{c}0.1468 \\
(2.3739)\end{array}$ & $\begin{array}{c}0.0027 \\
(0.0628)\end{array}$ & $\begin{array}{c}0.0521 \\
(1.0444)\end{array}$ & $\begin{array}{c}0.0860 \\
(3.5515)\end{array}$ \\
\hline BM\&F(-1) & $\begin{array}{c}-0.1948 \\
(-7.4340)\end{array}$ & $\begin{array}{c}-0.2999 \\
(-6.2561)\end{array}$ & $\begin{array}{c}-0.0472 \\
(-2.4120)\end{array}$ & $\begin{array}{c}-0.1006 \\
(-1.3759)\end{array}$ & $\begin{array}{c}-0.5701 \\
(-6.7304)\end{array}$ & $\begin{array}{c}-0.1418 \\
(-3.3440)\end{array}$ & $\begin{array}{c}0.0954 \\
(2.7885)\end{array}$ & $\begin{array}{c}-0.6799 \\
(-17.1649)\end{array}$ & $\begin{array}{c}0.0253 \\
(1.3159)\end{array}$ \\
\hline BM\&F(-2) & & & & $\begin{array}{l}0.0205 \\
0.2731\end{array}$ & $\begin{array}{l}-0.3267 \\
-3.7486\end{array}$ & $\begin{array}{c}-0.1129 \\
(-2.5898)\end{array}$ & $\begin{array}{c}0.0580 \\
(1.7134)\end{array}$ & $\begin{array}{c}-0.2544 \\
(-6.4892)\end{array}$ & $\begin{array}{c}0.0097 \\
(0.5106)\end{array}$ \\
\hline BRL(-1) & $\begin{array}{c}0.1339 \\
(2.4315)\end{array}$ & $\begin{array}{c}-0.1684 \\
(-1.6710)\end{array}$ & $\begin{array}{c}-0.5106 \\
(-12.4246)\end{array}$ & $\begin{array}{c}0.7487 \\
(3.5984)\end{array}$ & $\begin{array}{c}-0.3169 \\
(-1.3149)\end{array}$ & $\begin{array}{c}-0.0450 \\
(-0.3739)\end{array}$ & $\begin{array}{c}0.8868 \\
(9.6577)\end{array}$ & $\begin{array}{c}0.0534 \\
(0.5020)\end{array}$ & $\begin{array}{c}-0.1040 \\
(-2.0166)\end{array}$ \\
\hline BRL(-2) & & & & $\begin{array}{c}0.3458 \\
(2.5921) \\
\end{array}$ & $\begin{array}{c}-0.0603 \\
(-0.3905) \\
\end{array}$ & $\begin{array}{c}-0.0261 \\
(-0.3378) \\
\end{array}$ & $\begin{array}{c}0.4807 \\
(7.0625) \\
\end{array}$ & $\begin{array}{c}-0.0719 \\
(-0.9125) \\
\end{array}$ & $\begin{array}{c}-0.0988 \\
(-2.5840) \\
\end{array}$ \\
\hline
\end{tabular}

TABLE IV-B. VECM RESULTS FOR CHINA

\begin{tabular}{|c|c|c|c|c|c|c|c|c|c|}
\hline & \multicolumn{3}{|c|}{ Before } & \multicolumn{3}{|c|}{ During } & \multicolumn{3}{|c|}{ After } \\
\hline & NYSE & SSE & CNY & NYSE & SSE & CNY & NYSE & SSE & CNY \\
\hline \multirow[t]{2}{*}{ Coint. Eq. } & -0.1141 & 0.6353 & -0.0196 & -0.2249 & -0.1913 & -0.0142 & -0.0839 & -0.2052 & 0.0174 \\
\hline & $(-3.8973)$ & $(8.9243)$ & $(-7.0993)$ & $(-3.0518)$ & $(-3.3622)$ & $(-5.9325)$ & $(-4.6260)$ & $(-9.7081)$ & $(14.7090)$ \\
\hline \multirow[t]{2}{*}{ NYSE(-1) } & -0.6897 & -0.3425 & -0.0185 & -0.5677 & 0.3076 & 0.0028 & -0.5497 & 0.1744 & -0.0065 \\
\hline & $(-13.9073)$ & $(-2.8389)$ & (3.9618) & $(-6.6598)$ & $(4.6746)$ & $(1.0092)$ & $(-16.5195)$ & $(4.4947)$ & $(-2.9963)$ \\
\hline \multirow[t]{2}{*}{ NYSE(-2) } & -0.3226 & -0.0452 & 0.0082 & -0.4029 & 0.1571 & 0.0002 & & & \\
\hline & $(-7.0470)$ & $(-0.4059)$ & $(1.8952)$ & $(-5.0515)$ & $(2.5525)$ & $(0.0896)$ & & & \\
\hline SSE(-1) & $(-1.6535)$ & -3.6344 & $(-6.2773)$ & (1.6917) & $(-5.7058)$ & (5.9337) & (1.9787) & $(-9.5234)$ & $(-7.8793)$ \\
\hline \multirow[t]{2}{*}{ SSE(-2) } & -0.0655 & -0.1961 & -0.0055 & -0.1304 & -0.2621 & -0.0105 & & & \\
\hline & $(-3.1571)$ & $(-3.8841)$ & $(-2.8172)$ & $(-1.1374)$ & $(-2.9604)$ & $(2.8128)$ & & & \\
\hline \multirow[t]{2}{*}{ CNY(-1) } & 0.9244 & -9.0945 & -0.9833 & 10.1827 & 7.8590 & -0.1114 & -2.6924 & -4.5703 & -0.2110 \\
\hline & $(1.5466)$ & $(-6.2548)$ & $(-6.9022)$ & $(2.6267)$ & $(2.6259)$ & $(-0.8826)$ & $(-4.6168)$ & $(-6.7212)$ & $(-5.5609)$ \\
\hline \multirow[t]{2}{*}{ CNY(-2) } & 0.2186 & -4.2814 & -0.2270 & 1.9229 & 0.6796 & -0.499 & & & \\
\hline & $(0.4395)$ & $(-3.5382)$ & $(-4.8363)$ & $(0.6914)$ & $(0.3165)$ & $(-0.5520)$ & & & \\
\hline
\end{tabular}

TABLE IV-C. VECM RESULTS FOR PAKISTAN

\begin{tabular}{|c|c|c|c|c|c|c|c|c|c|}
\hline & \multicolumn{3}{|c|}{ Before } & \multicolumn{3}{|c|}{ During } & \multicolumn{3}{|c|}{ After } \\
\hline & NYSE & KSE & PKR & NYSE & KSE & PKR & NYSE & KSE & PKR \\
\hline Coint. Eq. & $\begin{array}{c}-0.0318 \\
(-1.5229)\end{array}$ & $\begin{array}{c}0.1740 \\
(7.1234)\end{array}$ & $\begin{array}{c}0.0800 \\
(10.7495)\end{array}$ & $\begin{array}{c}-0.0366 \\
(-1.6793)\end{array}$ & $\begin{array}{c}0.0442 \\
(0.5110)\end{array}$ & $\begin{array}{c}0.0030 \\
(9.9555)\end{array}$ & $\begin{array}{c}-0.0132 \\
(-0.3983)\end{array}$ & $\begin{array}{c}-0.1946 \\
(-2.0133)\end{array}$ & $\begin{array}{c}0.0238 \\
(18.5521)\end{array}$ \\
\hline NYSE(-1) & $\begin{array}{c}-0.7694 \\
(-15.8615)\end{array}$ & $\begin{array}{c}-0.1237 \\
(-2.1783)\end{array}$ & $\begin{array}{c}-0.0743 \\
(-4.2970)\end{array}$ & $\begin{array}{c}-0.4615 \\
(-5.4647)\end{array}$ & $\begin{array}{c}-0.0031 \\
(-2.0989)\end{array}$ & $\begin{array}{l}-0.0135 \\
(-1.2230)\end{array}$ & $\begin{array}{c}-0.7322 \\
(-18.8578)\end{array}$ & $\begin{array}{c}0.0455 \\
(0.1146)\end{array}$ & $\begin{array}{c}-0.0172 \\
(-3.2586)\end{array}$ \\
\hline
\end{tabular}




\begin{tabular}{|c|c|c|c|c|c|c|c|c|c|}
\hline NYSE(-2) & $\begin{array}{c}-0.3531 \\
(-7.5080)\end{array}$ & $\begin{array}{c}-0.1146 \\
(-2.0801)\end{array}$ & $\begin{array}{c}-0.0284 \\
(-1.6896)\end{array}$ & & & & $\begin{array}{c}-0.2576 \\
(-6.7536)\end{array}$ & $\begin{array}{c}0.0334 \\
(0.0855)\end{array}$ & $\begin{array}{c}-0.0075 \\
(-1.4540)\end{array}$ \\
\hline KSE(-1) & $\begin{array}{c}-0.0313 \\
(-0.5493)\end{array}$ & $\begin{array}{c}-0.1645 \\
(-2.4645)\end{array}$ & $\begin{array}{c}0.1475 \\
(7.2501)\end{array}$ & $\begin{array}{c}0.0663 \\
(0.3080)\end{array}$ & $\begin{array}{c}-0.3766 \\
(-4.3921)\end{array}$ & $\begin{array}{c}-0.0431 \\
(-1.4327)\end{array}$ & $\begin{array}{c}-6.65 \mathrm{E}-05 \\
(-0.0182)\end{array}$ & $\begin{array}{c}-0.8081 \\
(-21.5071)\end{array}$ & $\begin{array}{c}-0.0014 \\
(-2.8731)\end{array}$ \\
\hline KSE(-2) & $\begin{array}{c}-0.0241 \\
(-0.5286)\end{array}$ & $\begin{array}{c}-0.0593 \\
(-1.1085)\end{array}$ & $\begin{array}{c}0.0430 \\
(2.6362)\end{array}$ & & & & $\begin{array}{c}0.0072 \\
(1.9906)\end{array}$ & $\begin{array}{c}-0.3897 \\
(-1.4357)\end{array}$ & $\begin{array}{c}-0.0005 \\
(-0.9797)\end{array}$ \\
\hline PKR(-1) & $\begin{array}{c}-0.2641 \\
(-1.5546)\end{array}$ & $\begin{array}{c}1.2102 \\
(6.0841)\end{array}$ & $\begin{array}{c}-0.1924 \\
(-3.1740)\end{array}$ & $\begin{array}{c}-0.7539 \\
(-1.1553)\end{array}$ & $\begin{array}{c}-0.0607 \\
(-0.2336)\end{array}$ & $\begin{array}{c}0.1668 \\
(1.8268)\end{array}$ & $\begin{array}{c}-0.5593 \\
(-1.2188)\end{array}$ & $\begin{array}{l}-12.1014 \\
(-2.5701)\end{array}$ & $\begin{array}{c}0.2818 \\
(4.5163)\end{array}$ \\
\hline \multirow[t]{4}{*}{$\operatorname{PKR}(-2)$} & $\begin{array}{c}-0.2607 \\
(-2.0920)\end{array}$ & $\begin{array}{c}0.6989 \\
(4.7906) \\
\end{array}$ & $\begin{array}{c}-0.2082 \\
(-4.6835)\end{array}$ & & & & $\begin{array}{c}-0.2951 \\
(-1.0062)\end{array}$ & $\begin{array}{c}-6.4417 \\
(-2.1406)\end{array}$ & $\begin{array}{c}0.1013 \\
(2.5403)\end{array}$ \\
\hline & \multicolumn{9}{|c|}{ TABLE IV-D. VECM RESULTS FOR INDIA } \\
\hline & \multicolumn{3}{|c|}{ Before } & \multicolumn{3}{|c|}{ During } & \multicolumn{3}{|c|}{ After } \\
\hline & NYSE & BSE & INR & NYSE & BSE & INR & NYSE & BSE & INR \\
\hline Coint. Eq. & $\begin{array}{c}-0.7218 \\
(-10.1228)\end{array}$ & $\begin{array}{c}0.8994 \\
(7.5543)\end{array}$ & $\begin{array}{c}0.1617 \\
(5.9867)\end{array}$ & $\begin{array}{c}-0.5529 \\
(-3.2864)\end{array}$ & $\begin{array}{c}0.0668 \\
(0.4397)\end{array}$ & $\begin{array}{c}-0.2616 \\
(-7.2397)\end{array}$ & $\begin{array}{c}-0.6273 \\
(-9.3320)\end{array}$ & $\begin{array}{c}0.3521 \\
(4.7953)\end{array}$ & $\begin{array}{c}-0.3111 \\
(-14.3037)\end{array}$ \\
\hline NYSE(-1) & $\begin{array}{c}-0.1983 \\
(-3.8280)\end{array}$ & $\begin{array}{c}-0.4040 \\
(-4.6694)\end{array}$ & $\begin{array}{c}-0.0649 \\
(-3.3070)\end{array}$ & $\begin{array}{l}-0.3058 \\
(-2.1915)\end{array}$ & $\begin{array}{c}-0.0108 \\
(-0.0856)\end{array}$ & $\begin{array}{c}0.1793 \\
(5.9831)\end{array}$ & $\begin{array}{c}-0.2887 \\
(-4.7081)\end{array}$ & $\begin{array}{c}-0.2148 \\
(-3.2070)\end{array}$ & $\begin{array}{c}0.1864 \\
(9.4127)\end{array}$ \\
\hline NYSE(-2) & & & & $\begin{array}{l}-0.2744 \\
(-2.7777)\end{array}$ & $\begin{array}{c}-0.0044 \\
(-0.0494)\end{array}$ & $\begin{array}{c}0.0886 \\
(4.1774)\end{array}$ & $\begin{array}{c}-0.0378 \\
(-0.8743)\end{array}$ & $\begin{array}{c}-0.0722 \\
(-1.5296)\end{array}$ & $\begin{array}{c}0.0711 \\
(5.0865)\end{array}$ \\
\hline BSE(-1) & $\begin{array}{c}-0.1684 \\
(-6.3695)\end{array}$ & $\begin{array}{c}-0.3844 \\
(-8.7087)\end{array}$ & $\begin{array}{c}0.0223 \\
(2.2308)\end{array}$ & $\begin{array}{c}-0.0754 \\
(-0.8063)\end{array}$ & $\begin{array}{c}-0.6975 \\
(-8.2210)\end{array}$ & $\begin{array}{c}0.0190 \\
(0.9408)\end{array}$ & $\begin{array}{c}-0.1485 \\
(-4.2691)\end{array}$ & $\begin{array}{c}-0.6427 \\
(-16.9107)\end{array}$ & $\begin{array}{c}-0.0400 \\
(-3.5655)\end{array}$ \\
\hline BSE(-2) & & & & $\begin{array}{c}0.0648 \\
(0.7043)\end{array}$ & $\begin{array}{c}-0.3851 \\
(-4.6237)\end{array}$ & $\begin{array}{c}0.0258 \\
(1.3039\end{array}$ & $\begin{array}{c}-0.0553 \\
(-1.6231)\end{array}$ & $\begin{array}{c}-0.3338 \\
(-8.9747)\end{array}$ & $\begin{array}{c}-0.0215 \\
(-0.9574)\end{array}$ \\
\hline INR(-1) & $\begin{array}{c}-0.4110 \\
(-3.6830)\end{array}$ & $\begin{array}{c}0.5141 \\
(2.7646)\end{array}$ & $\begin{array}{c}-0.4564 \\
(-10.8208)\end{array}$ & $\begin{array}{c}1.8465 \\
(3.5484)\end{array}$ & $\begin{array}{c}0.2160 \\
(0.4590)\end{array}$ & $\begin{array}{c}-0.0498 \\
(-0.4457)\end{array}$ & $\begin{array}{c}1.1506 \\
(7.6937)\end{array}$ & $\begin{array}{c}-0.7749 \\
(-4.7435)\end{array}$ & $\begin{array}{c}-0.1412 \\
(-2.9222)\end{array}$ \\
\hline INR(-2) & & & & $\begin{array}{c}0.6675 \\
(1.7000)\end{array}$ & $\begin{array}{c}0.0824 \\
(0,2321)\end{array}$ & $\begin{array}{c}-0.0917 \\
(-1.0870)\end{array}$ & $\begin{array}{c}0.5939 \\
(5.2938)\end{array}$ & $\begin{array}{c}-0.5287 \\
(-4.3138)\end{array}$ & $\begin{array}{c}-0.1122 \\
(-0.9350)\end{array}$ \\
\hline
\end{tabular}

